
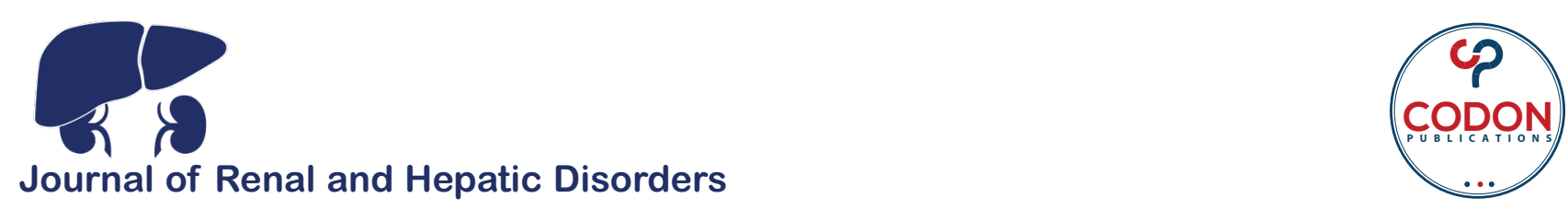

ORIGINAL ARTICLE NEPHROLOGY

\title{
Histological Evaluation of Extended Criteria Donors: Donor's Kidney Biopsy and Graft Outcome after 5 Years of Transplantation
}

\author{
Paolo Carta, Emma Bartaletti, Giulia Ghiandai, Leonardo Caroti, Aida Larti, Lorenzo Di Maria, \\ Lino Cirami
}

Nephrology Unit, Careggi University Hospital, Florence, Italy

\begin{abstract}
Pre-transplant kidney biopsy is routinely used to decide whether kidneys from marginal donors should be transplanted as single or double transplantation. This is a 5-year extension of the follow-up of a previous study. In that study, graft outcomes were compared retrospectively between a group of 44 recipients of a single kidney graft from an extended criteria donor and a Karpinski histological score of $\leq 3$, and another group of 56 recipients of a single transplant with a Karpinski histological score of 4 or 5 . After 5 years of transplantation, there was no difference between the two groups in terms of recipient's serum creatinine levels $(1.8 \pm 0.5 \mathrm{vs} 1.9 \pm 0.6 \mathrm{mg} / \mathrm{dL}, \mathrm{P}=0.5)$, creatinine clearance ( $53 \pm 23 \mathrm{vs} 49 \pm$ $27.0 \mathrm{~mL} / \mathrm{min}, \mathrm{P}=0.6)$, or the rates of graft loss $(41 \% \mathrm{vs} 49 \%, \mathrm{P}=0.5)$. Therefore, the choice between single and double transplant should not be made only on the basis of histological score but should be done together with the evaluation of donor's clinical parameters, especially the renal function.
\end{abstract}

Keywords: extended criteria donors; Karpinski histological score; kidney transplantation; pre-implantation kidney biopsy

Received: 29 May 2020; Accepted after Revision: 29 October 2020; Published: 07 November 2020

Author for correspondence: Dr. Paolo Carta, Nephrology Unit, Careggi University Hospital, Viale Pieraccini 18, 50134 Florence, Italy. Email: cartapa@aou-careggi.toscana.it

How to cite: Paolo Carta. Donor's Kidney Biopsy and Graft Outcome after 5 Years of Transplantation. J Ren Hepat Disord. 2020;4(2): 61-66.

Doi: https://doi.org/10.15586/jrenhep.v4i2.77

Copyright: Paolo Carta

License: This open access article is licensed under Creative Commons Attribution 4.0 International (CC BY 4.0). http://creativecommons.org/

\section{Introduction}

Kidney transplantation is the best treatment for end-stage renal disease (ESRD), since it guarantees a better quality of life and longer patient survival than dialysis (1). Although the use of extended criteria donors (ECDs) (2-4), dual kidney transplantation, non-heart beating donors (5), living and kidney paired donation (6), and ABO-incompatible transplantation (7) has increased the number of transplantations performed every year, the gap between organ's demand and offer is still increasing. Although in this era researchers are investigating the promising potential of regenerative nephrology (8), an important area of research is directed to increase the number of transplantation by optimization of the usage of kidneys harvested from "always more marginal donors" to find the border between a transplantable organ and an insufficient renal function.

Pre-implantation kidney biopsy is a tool to define organ transplantability and to distinguish whether a kidney from an ECD should be allocated as a single kidney transplant (SKT) or a double kidney transplant (DKT) (9). Until a few years ago, in our country, most of the transplant centers 
allocated kidneys to either SKT or DKT if the Karpinski histological score (10) was $\leq 3$ or $4-6$, respectively, according to the protocol described by Remuzzi et al. $(11,12)$. It is a common practice nowadays to be less stringent with this threshold, and today most of the transplant centers choose an SKT even if the Karpinski histological score is 4 or 5, but this choice is based more on the experience of the transplant center, rather than on the results of published studies.

In a previous study (13), we observed that SKT was performed with the Karpinski histological score of $\leq 3$ as well as the score of 4 or 5 after 3 years of follow-up, provided that the donor had a good renal function (estimated Glomerular Filtration Rate $[\mathrm{eGFR}]>55 \mathrm{~mL} / \mathrm{min}$ ) at the time of organ harvesting. This is a 5-year follow-up extension of our previous study to see whether the non-inferior outcomes of kidneys with the worst pathological lesions are maintained in the long term.

\section{Materials and methods}

Materials and methods are described in detail in our original work (13).
Briefly, we selected from our cohort of transplanted patients 100 consecutive recipients of an SKT from an ECD with an eGFR of at least $55 \mathrm{~mL} / \mathrm{min}$ at the time of organ retrieval. Of these, after 5 years of follow-up, we compared retrospectively 44 recipients with a pre-implantation Karpinski histological score of $\leq 3$ and 56 recipients who had a Karpinski histological score of 4 or 5 .

Basal characteristics of both donors and recipients are compared in the original paper and reported here in Table 1 for completeness.

We compared renal function in terms of creatinine and creatinine clearance using Student's $t$-test for independent samples or the Wilcoxon's rank-sum test, as appropriate. Graft survival was compared using the Kaplan-Meier and log-rank tests.

\section{Results}

\section{Donor characteristics}

As discussed in our previous paper (13), the baseline characteristics of donors and recipients were similar in the two groups and are reviewed in Tables 1 and 2.

Table 1: Donors' characteristics.

\begin{tabular}{|c|c|c|c|}
\hline & Group A & Group B & $\mathbf{P}$ \\
\hline Males (\%) & 43.2 & 48.2 & 0.61 \\
\hline $\begin{array}{l}\text { Age (years) } \\
\text { Median age }\end{array}$ & $\begin{array}{l}71.72 \pm 4.59 \\
71.5\end{array}$ & $\begin{array}{l}68.03 \pm 4.73 \\
68\end{array}$ & $<0.01$ \\
\hline $\begin{array}{l}\text { Creatinine levels }(\mathrm{mg} / \mathrm{dL}) \\
\text { Median level }\end{array}$ & $\begin{array}{l}0.85 \pm 0.30 \\
0.82\end{array}$ & $\begin{array}{l}0.83 \pm 0.24 \\
0.80\end{array}$ & 0.381 \\
\hline $\begin{array}{l}\text { eGFR }(\mathrm{mL} / \mathrm{min}) \\
\text { Median }\end{array}$ & $\begin{array}{l}76.39 \pm 26.53 \\
70.83\end{array}$ & $\begin{array}{l}85.8 \pm 28.2 \\
83.35\end{array}$ & 0.013 \\
\hline $\begin{array}{l}\text { Kidney longitudinal dimension by ultrasound (mm) } \\
\text { Median }\end{array}$ & $\begin{array}{l}107.54 \pm 9.4 \\
110\end{array}$ & $\begin{array}{l}108 \pm 8.0 \\
110\end{array}$ & 0.893 \\
\hline Hypertension (\%) & 31.8 & 50 & 0.10 \\
\hline $\begin{array}{l}\text { Donor's cause of death } \\
\text { Cardiovascular } \\
\text { Non-cardiovascular }\end{array}$ & $\begin{array}{l}38(86.4 \%) \\
6(13.6 \%)\end{array}$ & \multicolumn{2}{|l|}{$\begin{array}{l}40(71.4 \%) \\
16(28.6 \%)\end{array}$} \\
\hline & \multicolumn{2}{|c|}{ Group A } & Group B \\
\hline Karpinski’s histological score & $\begin{array}{c}\text { Score } 1: 2(4.5 \%) \\
\text { Score 2: } 13(29.5 \%) \\
\text { Score 3: } 29(65.9 \%)\end{array}$ & \multicolumn{2}{|c|}{$\begin{array}{l}\text { Score } 4: 32(57.1 \%) \\
\text { Score } 5: 24(42.9 \%)\end{array}$} \\
\hline Vascular score & $\begin{array}{c}\text { Score 0: } 4(9.1 \%) \\
\text { Score 1: } 38(86.4 \%) \\
\text { Score 2: } 2(8.3 \%)\end{array}$ & \multicolumn{2}{|c|}{$\begin{array}{l}\text { Score 1: } 34(60.7 \%) \\
\text { Score 2: } 22(39.3 \%)\end{array}$} \\
\hline
\end{tabular}

eGFR: estimated glomerular filtration rate. 
Table 2: Recipients' characteristics and results 5 years after transplantation.

\begin{tabular}{|c|c|c|c|}
\hline & Group A & Group B & $\mathbf{P}$ \\
\hline $\begin{array}{l}\text { Cold ischemia time (hours) } \\
\text { Median }\end{array}$ & $\begin{array}{c}18.0 \pm 7.2 \\
19\end{array}$ & $\begin{array}{c}19.6 \pm 6.5 \\
22\end{array}$ & 0.17 \\
\hline $\begin{array}{l}\text { HLA mismatches } \\
\text { Median (quartiles) }\end{array}$ & $\begin{array}{c}4 \\
(3-4)\end{array}$ & $\begin{array}{c}4 \\
(3-4.75)\end{array}$ & 0.263 \\
\hline Creatinine levels (mg/dL) & $1.8 \pm 0.5$ & $1.9 \pm 0.6$ & 0.5 \\
\hline eGFR (mL/min) & $53 \pm 23$ & $49 \pm 27$ & 0.6 \\
\hline Age (years) & $60.18 \pm 6.09$ & $60.33 \pm 6.07$ & 1.0 \\
\hline Males & $32(72.7 \%)$ & $40(73.2 \%)$ & 1.0 \\
\hline DGF & $25(58.1 \%)$ & $22(39.3 \%)$ & 0.063 \\
\hline $\begin{array}{l}\text { Cause of renal failure } \\
\text { ADPKD } \\
\text { Chronic GN } \\
\text { Nephrosclerosis } \\
\text { Unknown } \\
\text { IgAN } \\
\text { Diabetes } \\
\text { Others }\end{array}$ & $\begin{array}{c}8(18.2 \%) \\
9(20.5 \%) \\
10(22.7 \%) \\
6(13.6 \%) \\
2(4.5 \%) \\
0 \\
9(20.5 \%)\end{array}$ & $\begin{array}{c}13(23.2 \%) \\
8(14.3 \%) \\
7(12.5 \%) \\
8(14.3 \%) \\
5(8.9 \%) \\
3(5.2 \%) \\
12(21.4 \%)\end{array}$ & \\
\hline Biopsy proven acute rejection & $8(18.2 \%)$ & $8(14.3 \%)$ & 0.598 \\
\hline Return to dialysis & $5(11 \%)$ & $9(17 \%)$ & 0.7 \\
\hline Death with a functioning graft & $13(30 \%)$ & $17(32 \%)$ & 0.43 \\
\hline $\begin{array}{l}\text { Cause of death } \\
\text { Infections } \\
\text { Cardiovascular } \\
\text { Neoplastic } \\
\text { Others }\end{array}$ & $\begin{array}{c}58.3 \% \\
33.3 \% \\
8.4 \%\end{array}$ & $\begin{array}{l}61.1 \% \\
11.1 \% \\
27.7 \%\end{array}$ & \\
\hline
\end{tabular}

Continuous variables are expressed as mean values \pm standard deviation, except for HLA mismatch (expressed as median values and quartiles). ADPKD: autosomal dominant polycystic kidney disease; GN: glomerulonephritis; IgAN: IgA nephropathy; HLA: human leukocyte antigen; eGFR: estimated glomerular filtration rate; DGF: delayed graft function.

Renal function after 5 years of transplantation was not different between the two groups in terms of serum creatinine levels $(1.8 \pm 0.5$ vs $1.9 \pm 0.6 \mathrm{mg} / \mathrm{dL}, \mathrm{P}=0.5)$ or eGFR $(53 \pm 23$ vs $49 \pm 27.0 \mathrm{~mL} / \mathrm{min}, \mathrm{P}=0.6)$.

\section{Survival analysis}

Patient survival after 5 years was $72 \%$ and $64 \%$ in groups $\mathrm{A}$ and $\mathrm{B}$, respectively. The cause of death was related to infectious complications in $58.3 \%$, cardiovascular disease in $33.3 \%$, and malignancies in $8.4 \%$ of recipients in group A, while in group B, the cause of death was related to infection in $61.1 \%$, cardiovascular disease in $11.1 \%$, and other causes in $27.7 \%$ of recipients. Death-censored graft survival was $90.7 \%$ and $86.8 \%$ of patients in groups A and $\mathrm{B}$, respectively.

The Kaplan-Meier curves of death uncensored graft survival are shown in Figure 1. The log-rank analyses of both curves did not reveal any statistically significant difference in 5-year graft survival $(\mathrm{P}=0.41)$ between the two groups. In the Cox regression, cold ischemia time and recipient's age were the only covariates that had an influence on graft survival (Table 3).

\section{Other parameters}

As reported in our previous study, other parameters that we evaluated might have had an influence on graft survival or 
Table 3: Cox regression.

\begin{tabular}{|c|c|c|c|c|}
\hline & \multirow[t]{2}{*}{ HR } & \multicolumn{2}{|c|}{$95 \%$ CI } & \multirow[t]{2}{*}{$\mathbf{P}$} \\
\hline & & Inferior & Superior & \\
\hline Recipient's age & 1.071 & 1.004 & 1.142 & 0.036 \\
\hline Donor's age & 0.976 & 0.904 & 1.054 & 0.540 \\
\hline Cold ischemia & 1.133 & 1.016 & 1.264 & 0.025 \\
\hline Donor's serum creatinine & 3.155 & 0.748 & 13.305 & 0.118 \\
\hline Histological score $1-3$ or $4-5$ & 0.663 & 0.311 & 1.413 & 0.287 \\
\hline Kidney longitudinal dimension & 1.004 & 0.961 & 1.048 & 0.866 \\
\hline Acute rejection & 0.487 & 0.193 & 1.227 & 0.127 \\
\hline DGF & 0.942 & 0.461 & 1.925 & 0.870 \\
\hline
\end{tabular}

DGF: delayed graft function; 95\% CI: 95\% confidence interval.

renal function were not statistically diffrentin both groups. The rate of acute rejection has been $18 \%$ and $14 \%$ in groups $\mathrm{A}$ and $\mathrm{B}$, respectively. The rate of delayed graft function was comparable in both groups ( $56 \%$ vs $39 \%$; $\mathrm{P}=0.06)$.

\section{Discussion}

In this study, we compared retrospectively the graft outcomes and renal function 5 years after transplantation of SKT harvested from ECD withthe standard Karpisnki histological score (KS $\leq 3$, Group A) versus SKT with a score usually transplanted as DKT (KS $=4$ or 5 , Group B). The histological criteria to allocated kidneys from ECD donors are based on the Remuzzi study (12).

Our data analysis confirms the results obtained in the previous study, which compared the outcomes after 2 years of the transplant (13): there are no statistically significant differences for organ survival between the two groups. A good kidney function can guarantee a good organ survival regardless of the histological score (provided $\leq 5$ ). Five-year organ survival is similar between the two groups $(\mathrm{P}=0.4)$ and it's the same for patient survival $(\mathrm{P}=0.61)$.

This study could underline the importance of the evaluation of donor's renal function in addition to the histological score.

In literature we can find other studies on ECD that agree with our study.

In 2017, Escuredo et al. (14) published a study on organ allocation based on the Kidney Donor Profile Index (KDPI) and Pretransplant Donor Biopsies (PTDB). The cited study analyzes the problem of allocation decision in the manner opposite to ours, that is, at many centers, kidneys with KDPI $>85 \%$ are discarded. They compared the survival of kidney after 5 years between patient groups with PTDB based on the Remuzzi score of $\leq 4$ and different KDPI. The cited study concludes that organs with KDPI > 91\% and PTDB based on the Remuzzi score $=4$ are suitable for assignment to SKT, with guarantee of good survival despite the high calculated risk and high Remuzzi score. This study underlines that it is essential to integrate clinical data with biopsy data, while the exclusive use of one of the two methods is excessively restrictive.

In 2015, Wang et al. (15) published a systematic review of medical literature on the utility of both procurement and implantation biopsies for predicting post-transplant outcomes. Between January 1, 1994 and July 1, 2014, 47 studies were published that examined the association between pretransplant donor biopsy findings of 50 or more donors (with more than half being from deceased donors) and either post-transplant graft failure, delayed graft function, or graft function. Of 15 semiquantitative scoring systems proposed, none consistently predicted post-transplant outcomes across studies, suggesting that the role of pretransplant kidney biopsy may be reconsiderated.

We recognize limitations of our study: it is a retrospective study, analyzes the data of a single center, and takes into consideration a small patient population.

Another aspect to underline concerns is histology: biopsy analyses can be influenced by operator-dependent variability. The transplants selected in the study were performed within a 5-year period. A 5-year follow-up is enough period to predict long-term survival of transplant in the group with the worst histological score.

The age and glomerular filtrate of donors are statistically different between the two groups; paradoxically, group B donors have better basal characteristics. Comparing data, 


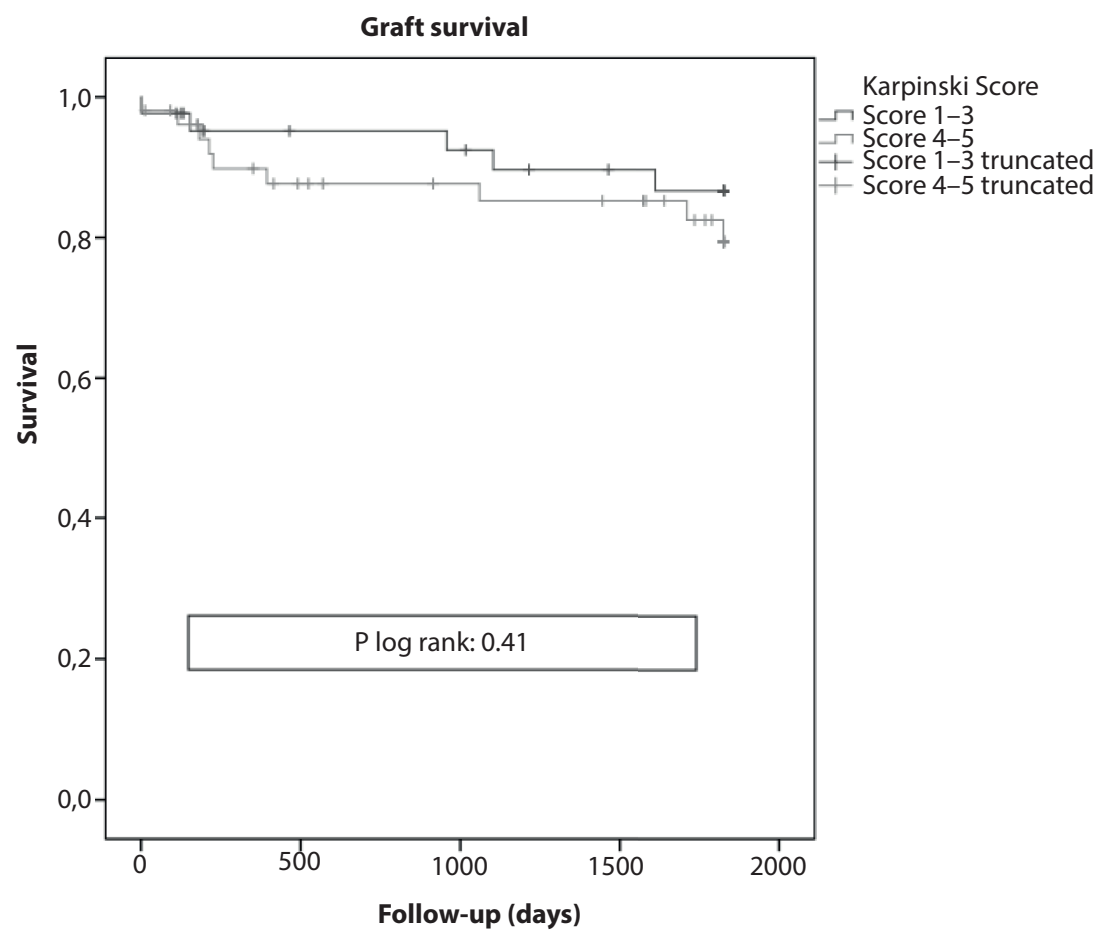

Figure 1: Kaplan-Meier curves for graft survival.

group B donors are younger than 3 years and have an average glomerular filtrate of $9 \mathrm{~mL} / \mathrm{min}$ better than group $\mathrm{A}$ donors.

We do not consider this a mistake because it has been shown to have no impact on survival, rather these differences underline the main purpose of the study: to safely allocate kidneys with a histological score of $4-5$ for SKT, we must pay particular attention to select only kidneys with preserved renal function.

Immunosuppressive therapy needs a further comment. A slightly higher percentage of group B recipients were treated with immunosuppressant Everolimus.

This could lead one to suspect that the difference in GFR in favor of group B recipients is due to a reduced exposure to calcineurin inhibitor. However, we believe this doubt to be unfounded because only $13 \%$ of the group B patients were treated with mTOR-i, and therefore the difference in GFR cannot be attributed only to exposure to cyclosporine.

\section{Conclusions}

Our study confirms that with an accurate selection of donor, transplantation of a kidney with a Karpinski histological score 4 or 5 is a safe strategy. This allowed us to increase the number of ECD transplantations by $23 \%$, and the total number of transplants by $9 \%$, without any evident adverse effect on transplant outcomes after 5 years.

\section{References}

1. Wolfe RA, Ashby VB, Milford EL, et al. Comparison of mortality in all patients on dialysis, patients on dialysis awaiting transplantation, and recipients of a first cadaveric transplant. N Engl J Med. 1999 Dec 2;341(23):1725-30. http://dx.doi.org/10.1056/ NEJM199912023412303

2. Pascual J, Zamora J, Pirsch JD. A systematic review of kidney transplantation from expanded criteria donors. Am J Kidney Dis. 2008 Sep;52(3):553-86. http://dx.doi.org/10.1053/j. ajkd.2008.06.005

3. Maggiore U, Cravedi P. The marginal kidney donor. Curr Opin Organ Transplant. 2014 Aug;19(4):372-80. http://dx.doi. org/10.1097/MOT.0000000000000081

4. Stallone G, Infante B, Gesualdo L. Older donors and older recipients in kidney transplantation. J Nephrol. 2010 SepOct;23(Suppl 15):S98-S103.

5. Summers DM, Watson CJ, Pettigrew GJ, Johnson RJ, Collett D, Neuberger JM, et al. Kidney donation after circulatory death (DCD): State of the art. Kidney Int. 2015 Aug;88(2):241-9. http://dx.doi.org/10.1038/ki.2015.88

6. Ferrari P, Weimar W, Johnson RJ, Lim WH, Tinckam KJ. Kidney paired donation: Principles, protocols and programs. Nephrol Dial Transplant. 2015 Aug;30(8):1276-85. http://dx. doi.org/10.1093/ndt/gfu309

7. Böhmig GA, Farkas AM, Eskandary F, Wekerle T. Strategies to overcome the $\mathrm{ABO}$ barrier in kidney transplantation. Nat Rev Nephrol. 2015 Dec;11(12):732-47.

8. Humphreys BD. Kidney injury, stem cells and regeneration. Curr Opin Nephrol Hypertens. 2014;23(1):25-31. http://dx.doi. org/10.1097/01.mnh.0000437332.31418.e0 
9. Randhawa P. Role of donor kidney biopsies in renal transplantation. Transplantation. 2001 May 27;71(10):1361-5. http://dx. doi.org/10.1097/00007890-200105270-00001

10. Karpinski J, Lajoie G, Cattran D, et al. Outcome of kidney transplantation from high-risk donors is determined by both structure and function. Transplantation. 1999 Apr 27;67(8):1162-7. http://dx.doi.org/10.1097/00007890-199904270-00013

11. Remuzzi G, Grinyò J, Ruggenenti P, Beatini M, Cole EH, Milford EL, Brenner BM. Early experience with dual kidney transplantation in adults using expanded donor criteria. Double Kidney Transplant Group (DKG). J Am Soc Nephrol. 1999 Dec; 10(12):2591-8.

12. Remuzzi G, Cravedi P, Perna A, et al. Long-term outcome of renal transplantation from older donors. N Engl J Med. 2006 Jan 26;354(4):343-52. http://dx.doi.org/10.1056/NEJMoa052891
13. Carta P, Zanazzi M, Caroti L, Buti E, Mjeshtri A, Di Maria L, et al. Impact of the pre-transplant histological score on 3-year graft outcomes of kidneys from marginal donors: A single-centre study. Nephrol Dial Transplant. 2013 Oct;28(10):2637-44. http://dx.doi.org/10.1093/ndt/gft292

14. Escuredo AS, Sagasta A, Revuelta I, Rodas LM, Paredes D, Musquera M, et al. Histopathological evaluation of pretransplant donor biopsies in expanded criteria donors with high kidney donor profile index: A retrospective observational cohort study. Transpl Int. 2017 Oct;30(10):975-86. http://dx.doi. org/10.1111/tri.12966

15. Wang CJ, Wetmore JB, Crary GS, Kasiske BL. The donor kidney biopsy and its implications in predicting graft outcomes: A systematic review. Am J Transplant. 2015 Jul;15(7):1903-14. http://dx.doi.org/10.1111/ajt.13213 